\title{
Community structure of free-floating filamentous cyanobacterial mats from the Wonder Lake geothermal springs in the Philippines
}

\author{
Donnabella C. Lacap, Gavin J.D. Smith, Kimberley Warren-Rhodes, and \\ Stephen B. Pointing
}

\begin{abstract}
Cyanobacterial mats were characterized from pools of $45-60{ }^{\circ} \mathrm{C}$ in near-neutral $\mathrm{pH}$, low-sulphide geothermal springs in the Philippines. Mat structure did not vary with temperature. All mats possessed highly ordered layers of airspaces at both the macroscopic and microscopic level, and these appear to be an adaptation to a freefloating growth habit. Upper mat layers supported biomass with elevated carotenoid:chlorophyll $a$ ratios and an as yet uncharacterized waxy layer on the dorsal surface. Microscopic examination revealed mats comprised a single Fischerella morphotype, with abundant heterocysts throughout mats at all temperatures. Molecular analysis of mat community structure only partly matched morphological identification. All samples supported greater 16S rDNAdefined diversity than morphology suggested, with a progressive loss in the number of genotypes with increasing temperature. Fischerella-like sequences were recovered from mats occurring at all temperatures, but some mats also yielded Oscillatoria-like sequences, although corresponding phenotypes were not observed. Phylogenetic analysis revealed that Fischerella-like sequences were most closely affiliated with Fischerella major and the Oscillatoria-like sequences with Oscillatoria amphigranulata.
\end{abstract}

Key words: cyanobacteria, Fischerella, geothermal springs, microbial mats, Oscillatoria.

Résumé : Nous avons caractérisé des tapis des cyanobactéries provenant de mares de sources géothermiques des Philippines à $45-60^{\circ} \mathrm{C}$, d'un $\mathrm{pH}$ quasi-neutre et faibles en sulfures. La structure des tapis n'a pas varié avec la température. Tous les tapis renfermaient des couches hautement structurées d'espaces aériens tant au niveau macroscopique que microscopiques et celles-ci semblaient être une adaptation à la croissance par flottaison. Les couches supérieures des tapis contenaient une biomasse comportant un rapport caroténoïde:chlorophylle a élevé et une couche cireuse encore non caractérisée sur la surface dorsale. Un examen microscopique a révélé que les tapis renfermaient un seul morphotype de Fischerella avec de nombreux hétérokystes au travers des tapis à toutes les températures. L'analyse moléculaire de la structure de la communauté des tapis n'a que partiellement concordé avec l'identification morphologique. Tous les échantillons renfermaient une diversité définie par l'ADNr 16S supérieure à ce que la morphologie suggérait, avec une perte progressive du nombre de génotypes à mesure que la température augmentait. Des séquences semblables à Fischerella ont été prélevées des tapis ayant évolué à toutes les températures mais certains tapis ont également généré des séquences semblables à Oscillatoria bien qu'aucun phénotype correspondant ne fut observé. L'analyse phylogénétique a révélé que les séquences semblables à Fischerella se rapprochaient davantage de Fischerella major et que les séquences semblables à Oscillatoria s'apparentaient à Oscillatoria amphigranulata.

Mots clés : cyanobactéries, Fischerella, sources géothermiques, tapis microbiens, Oscillatoria.

[Traduit par la Rédaction]

\section{Introduction}

Geothermal springs are extreme aquatic environments presenting thermal and chemical challenges to life. Nonetheless, springs of neutral to alkaline $\mathrm{pH}$ support prokaryotic microbial mats that have photoautotrophic production and varying community structures (Ward and Castenholz 2000).
The species composition and community structure of thermophilic mats was first described for 2 geothermal spring systems in The Great Basin and Yellowstone National Park, USA, in the pioneering studies by Brock (1978), Castenholz (1973), Ward and co-workers (1987, 1989). Morphological examinations revealed several epilithic mat types with the filamentous cyanobacteria Calothrix,

Received 30 June 2004. Revision received 3 February 2005. Accepted 10 March 2005. Published on the NRC Research Press Web site at http://cjm.nrc.ca on 15 September 2005.

D.C. Lacap, G.J.D. Smith, and S.B. Pointing. ${ }^{1}$ Extremophiles Research Group, Department of Ecology and Biodiversity, The University of Hong Kong, Pokfulam Road, Hong Kong, China.

K. Warren-Rhodes. N.ASA Ames Research Center, Moffett Field, CA 94035, USA.

'Corresponding author (e-mail: pointing@hkucc.hku.hk). 
Mastigocladas (Fischerella). Oscillatoria, and Phormidium, variously occurring as the dominant photosynthetic organism. from channels of geothermally heated water at comperatures below 60 C. To date. there have been few molecular investigations of such filamentous mat communities, although several Oscillatoria sequences have been recovered from hot springs in Italy, Japan. and New Zealand (Papke et al. 2003). In addition. some moderately thermophilic Sincehococeus mats in Yellowstone Nattional Park have also been shown to support filamentous genotypes (Norris et al. 2002). The unicellular morphospecies Sinerhocoreus ef. lividus is the only cyanobacterial morphotype encountered at temperatures above of ' $\mathrm{C}$ (Ward and Castenholy 2000). Most recent research has focused on resolving community structure within such Synechococeus mats, largely from selected geothermal springs within the Great Basin and Yellowstone sites, using molecular techniques (Ferris et al. $1996 a$. 1996b: Ward et al. 1997). Such mats were found to vary little in terms of 16 S rDNA-defined diversity hoth seasonally and upon recovery from disturbance (Ferris and Ward 1997: Ferris et al. 1997: Norris et al. 2002). Very litule difference in $16 \mathrm{~S}$ rDNA-defined diversity of Simerhorecus-like seyuences was identified between those studied in geothermal springs up to $100 \mathrm{~km}$ apart in Yellowstone (Ward et al. 19981 .

Comparatively, few studies have recorded geothermal spring mat biodicersity in other locations with approaches generally using microscopy and enrichment culture to observe taxal. Sinechococelss and Oscillatoria appear to be commonly encountered in Asian (Arit 1997: Castenholy 1996: Panyoo and Pecrapornpisal 20(01). European (Pentecost 1995: Pentecost et al. 1997), and New Zealand (Castenholy 1976) geothermal springs. One recent study identified significantly different $16 \mathrm{~S}$ rDNA-defined lineages of Sinechococelus- and Oscillatoriatike sequences between north American. European. Japanese, and New Zealand geothermal springs (Papke et al. 2003). Since no correlation between aqueous geochemistry and diversity was identified. diversity was attributed. at least in part. 10 genetic drift resulting from the isolated natture of geothermal habitats. This highlights the need to study diversity in geothermal springs across environmental gradients over a wide biogeographical area. particularly the tropics that have not been well studied. In this study, both microscopic observation and molecular methods were used to characterize unusual filamentous mats from geothermal springs in the Philippines, yielding new data on thermophilic mat structure and envirommental 165 rDNA-defined thermophilic genotypes.

\section{Materials and methods}

\section{Sample collection}

Twenty-seven mat samples were collected using a hierarchical random sampling design from 3 separate pools $0.5 \mathrm{~m} t 08 \mathrm{~m}$ in depth in the Wonder Lake geothermal springs, Laguna. Philippines. The 3 pools were characterized as follows: the low-kemperature $\left(4.5\right.$ "C) pool was between $4+2-45.4{ }^{\circ} \mathrm{C}$. pH 6.93-7.17. and had a $30 \mu \mathrm{mol} / \mathrm{L}$. $\mathrm{H}_{2} \mathrm{~S}$ content; the midtemperature $(5.3$ "C) pool was between 52.5-5+ C. pH 6.987. and had $30 \mu \mathrm{mol} / \mathrm{l}$. $\mathrm{H}_{2} \mathrm{~S}$ : and the high-temperature $(60)^{\circ} \mathrm{C}$ ) poot was between 59.6-60.5 C. pH 6.81-6.83, and had 30 $\mu m o l / L, H_{2} S$. Mat samples $(2 \mathrm{~cm} \times 2 \mathrm{~cm}$ and varying thickness) were aseptically cut from selected mats using a scalpel and stored in sterile glass bottleson ice in the dark when in the field and then at $4{ }^{\circ} \mathrm{C}$ in the laboratory until processed (-1 week).

\section{Water chemistry}

Temperature and $\mathrm{pH}$ were recorded using a thermometer and digital $\mathrm{pH}$ meter with attomatic temperature compensation (Orion. Boston. Mass.). The hydrogen sulphide content of water was assessed by methylene blue titration using a HS-WR field test kit (Hach, Loveland, Co.) according to the manufacturers instructions.

\section{Microscopy}

All measurements and photographs were laken using either an Olympus SZHIO stereomicroscope or $B X 50$ compound microscope with differential interference contrast optics. both fitted with an Olympus DPII digital camerat.

\section{Pigment analysis}

The absorption spectra of pigments were measured spectrophotometrically (Spectronic Genesys 5: Thermo Electron Corp. Madison. Wis.) after extraction of biomass overnight in 10 volumes of absolute methanol.

\section{Polymerase chain reaction and denaturing gel gradient electrophoresis}

DNA extraction followed a previously described cetyltrimethylammonium bromide (CTAB) extraction protocol (Doyle and Doyle 1987 with the following modifications: RNAse A and proteinase $K$ incubations were included in the lysis step (final concentration $200 \mu \mathrm{g} / \mathrm{mL}$ ); and phenol - chloroform isoamyl alcohol (25:24:1) extratctions were carried out at 60) $C$ to maximize recovery from thick-walled cyanobacteria. 16.S rRNA genes were amplified by polymerase chain reaction (PCR) using cyanobacterial-specific primers CYA359F (GGGGAATYTTCCGCAATGGG) and CYA781R (GACTACWGGGGTATCTAATCCCWTT) (Nübel el al. 1997) with a 4() -bp GC clamp added to the forward primer and the following profile: 35 cycles of 1 min at $94^{\circ} \mathrm{C}, 50$ s at $52{ }^{\circ} \mathrm{C}$. I min at $72{ }^{\circ} \mathrm{C}$; with an initial denaturation step of 3 min and a final extension step of $10 \mathrm{~min}$. The PCRreaction mixture contained $1.5 \mathrm{mmol} / \mathrm{L}, \mathrm{MgCl}_{2},(0.2 \mathrm{mmol} / \mathrm{L}$

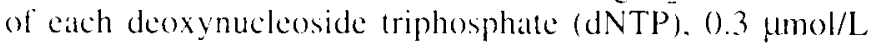
of each primer, and $1.0 \mathrm{U}$ of Taq DNA polymerase. We confirmed specificity of the cyanobacteria-specific PCR primers across a broad taxonomic range of 20 filamentous reference laxa from The University of Hong Kong Culture Collection (cyanobacteria). PCR products were separated by denaturing gel gradient electrophoresis (DGGE) as previously described (Myers et al. 1988). A $15 \%+4 \%$ ureaformamide denaturant gradient was used in a $7 \%$ acrylamide gel, run at $150 \mathrm{~V}$ for $5 \mathrm{~h}$ in $1 \times$ Tris - acetic acid - EDTA (TAE) buffer (pH 8) at 60 ${ }^{\circ} \mathrm{C}$ (DGGE-200) : C.B.S. Scientific Co.. Del Mar, Calif.).

\section{Sequence analysis}

Bands were excised. soaked overnight in Tris-EDTA (TE) buffer $(\mathrm{pH} 8)$ at 4 "C. re-amplified, and purified (Amersham 
Fig. 1. Structure of cyanobacterial mats from Wonder Lake geothermal springs. (a) Section through microbial mat revealing distinct macroscopic airspaces, bar represents $10 \mathrm{~mm} ;(b)$ section through microbial mat revealing microscopic airspaces, bar represents $50 \mu \mathrm{m}$; and (c) primary trichomes and heterocystous cells of Fischerella within mat, bar represents $10 \mu \mathrm{m}$.
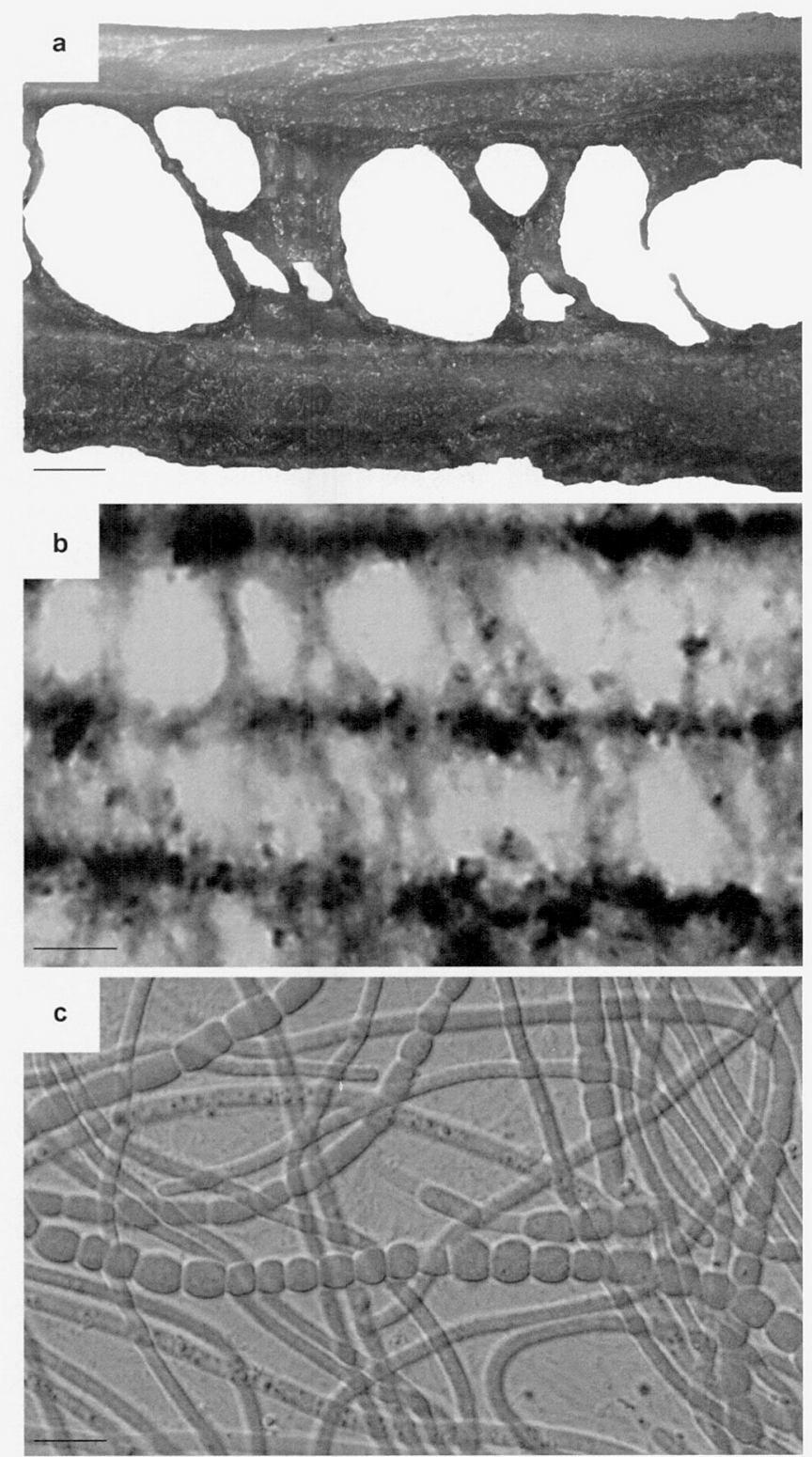

GFX Gel Band Purification Kit; Amersham Biosciences, Buckinghamshire, UK) prior to automated sequencing (ABI Prism 377; Applied Biosystems, Foster City, Calif.). Bands that could not be sequenced directly were cloned (pDrive Cloning Vector (PCR Cloning Kit); Qiagen Inc., Valencia, Calif.) before successful sequencing. Approximate phylogenetic affiliations were determined by BLAST searches of the NCBI GenBank database. Multiple alignments were then created with reference to selected GenBank sequences using BioEdit v. 5.0.9 (Hall 1999). Maximum likelihood analysis using PAUP* v. 4.0 b8 (Swofford 2001) was used to illustrate the relationship of partial $16 \mathrm{~S}$ rRNA gene sequences with representative cyanobacteria. Bayesian posterior proba-
Fig. 2. Denaturing gel gradient electrophoresis analysis of $16 \mathrm{~S}$ rDNA-defined cyanobacterial community structure in Wonder Lake cyanobacterial mats from (a) $45{ }^{\circ} \mathrm{C}$, (b) $53{ }^{\circ} \mathrm{C}$, and (c) $60{ }^{\circ} \mathrm{C}$ geothermal pools, with 3 replicates $(1-3)$ for each.

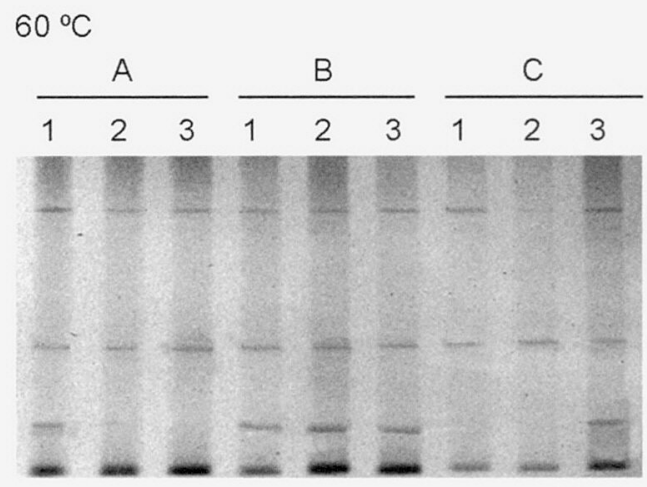

$53^{\circ} \mathrm{C}$

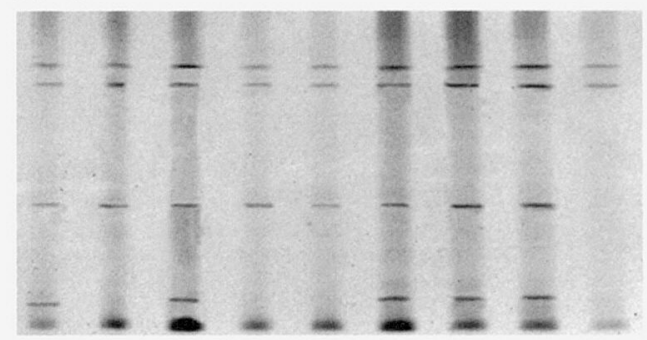

$45^{\circ} \mathrm{C}$

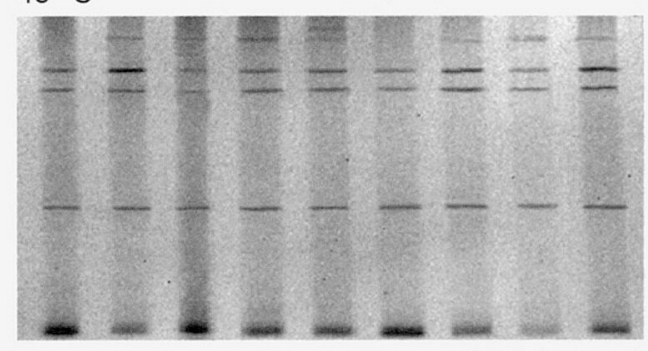

bilities (Rannala and Yang 1996) and bootstrap values (100 replications) were calculated and are shown for branches supported by more than $50 \%$ of the trees.

\section{Nucleotide sequence accession numbers}

All nucleotide sequences obtained during the course of this investigation have been deposited in GenBank under accession Nos. AY236467-AY236480.

\section{Results}

Filamentous mats were oxic throughout, with a thin upper yellow layer of biomass overlying a thicker lower green layer (Fig. 1a). The upper layer had a carotenoid:chlorophyll $a$ ratio of $-1: 1$, whereas in the lower layers it was $\sim 1: 2$. The dorsal surface was covered in a thin, non-cellular waxy layer. Microscopic analysis revealed an identical morphotype composition throughout all mats from 45 to $60^{\circ} \mathrm{C}$. Of great interest, there was the occurrence of macroscopic near-spherical airspaces arranged in a honeycomb-like pattern throughout the green layer of all mats (Fig. 1a). These airspaces had an estimated average volume of $7.43 \mathrm{~mm}^{3}$ (assuming spherical shape). Further 
Fig. 3. Phylogenetic relationships among Wonder Lake cyanobacterial mat sequences based upon Maximum Likelihood analysis of partial $16 \mathrm{~S}$ rRNA gene sequence data. The tree is supported by bootstrap values for 100 replications (first number) and Bayesian posterior probabilities (scoond number). shown for branches supported by more than 50 g of the trees. Scale har represents 0.1 nucleotide changes per position. Sequences derived from this study are shown with the prefix WL. Numbers after secpuence codes denote temperature from which sequence was obtained.

interest lies in the presence of highly ordered horizontal lavers of smaller near-spherical airspaces visible at the microscopic level between apparent "growth-lines" of debris and cellular material (Fig. 1b). These smaller airspaces had an estimaled average volume of $153 \mathrm{\mu m}^{3}$ (atssuming spheri(al shape) and were not bordered by a membrane but rather by densely packed cellular filaments

Microscopic analysis revealed mats to comprise filamentous Fischerella-like cells (Fig. I c) with numerous heterocystous eells and primary trichomes visible. No other morphotypes of either filamentous or unicellular cyanohateteria were observed. Since morphology of the filamentous mats was identical from pools of significantly different temperature, we investigated 165 rDNA-defined diversity using DGGE to establish any genetic diversity between mats within and between pools (Fig. 2). In all cases. template. PCR, and DGGE conditions were optimized and the number of hands obtained in all cases was comparable with that of other studies on thermophilic microbial mats. Six band migrattion classes were identified in samples from the lowtemperature pool $(4.5 \mathrm{C}) .5$ from the mid-temperature pool $15.3 \mathrm{C}$ (). and $t$ in the high-temperature pool $(6)^{\circ} \mathrm{C}$ (Fig 2). Sequenes from DGGE bands all displayed high similarity (>9)(\%) to Fischerella or Oscillatoria sequences ats revealed by BLAST searches of the NCBI GenBank database.

Phylogenetic analysis revealed sequences resolved into 2 distinct groups; one with the closest affiliation to Fischerella spp. and the other to Oscillatoria spp. (Fig. 3). The Fischerella-like sequences formed a closely related group with highest affinity to Fisherellla major from Japan and an uncultured fischerella sequence from an Leeland hot spring. The resolution of the genus, however, is not supported by high bootstrap or Bayesian values. No pattems separating seyuences obtained from different temperature poots were evident. although a single sequence from the lowest temperature pool branched on its own within the Fischerella lineage. The Oscillatoria-like sequences affiliated most closely with thermophilic Oscillatoria amphigramulata sequences also recovered from geothermal springs. and with one exception. they form what is probably at new lincage with moderate support.

\section{Discussion}

The themophilic mats described in this paper are interesting for 2 main reasons. The first reason being for the documentation of the free-floating growth form and apparent adaptations to this in terms of atrspates at the materoscopic and microscopic level. An additional adaptation to enviromment may lie in the carotenoid-rich layer of biomass and in the unidentified waxy layer in dorsal mat layers. Sec- ondly. the sequences obtained contribute to knowledge about the diversity of thermophilic cyanobacteria, notably for this Fischerella mat type. which has not been previously investigated at the community molecular level. The recovery of Oscillatoria-like sequences, which ate known from several studies of other geothermal regions, contributes data that may also be useful in further understanding the phylogeography of thermophilic filamentous cyanobatcteria.

The structural organization of the Wonder lake mats is of great interest. It is clear that the lilamentous nature of component species facilitates the creation of the macroscopic and microscopic airspaces within mats, and these airspaces appear to be maintained without a membranous surrounding. Such organization would probably not be possible in mats comprising only unicellular species. The method of formation for these airspaces is not clear al present. It is reasonable, however, to atssume that they function to provide buoyancy. A free-floating lifestyle may confer some advantage over epilithic growth in tropical geothermal springs such as Wonder Lake, where large seasonal fluctuations in water level and turbidity due to monsoon rains pools at Wonder Lake become several metres deeper and very turbid during the rainy season) may compromise the photosynthetic efficiency of attached mats as they become more deeply submerged, but floating mats can maintain their position on the water surface. Since the Wonder lake mats were also oxic throughout, it is possible that the airspaces fultill a role in maintaining acration throughout mats. This may explain why they do not support anacrobic layers commonly reported for unicellular thermophilic mat communities. It would be interesting to establish the method of formation and gaseous composition of these airspaces in situ through future study and to establish why such gases are not consumed by heterotrophic activity.

The high carotenoid levels in the upper layers of mats probably reflect a response to high UV exposure. Elevated carotenoid:chlorophyll a (and phycobilin) ratios are a wellknown response to high UV irradiance (Castenhol\% and Garciat-Pichel 2000), and since the UV-screening ability of carotenoids is minimal, it is assumed that an indirect role in UV-protection occurs by carotenoids acting as quenching agents for radicals and other reactive species. Elevated carotenoid levels are also known to oceur as a result of a deficiency in nitrogen (Collier and Grossman 1992), although this seems unlikely considering the diazotsophic nature of Fischerella. The nature of the as yet unidentified waxy surface layer of mats is unknown. Further work is necessary to elucidate its origin. composition, and function (if any) in UV-protection. Other mat-forming thermophilic cyanobacteria taxa including Colothrix and Plearocapsa produce UV-screening sheath pigments such as scytonemin (Garcia- 


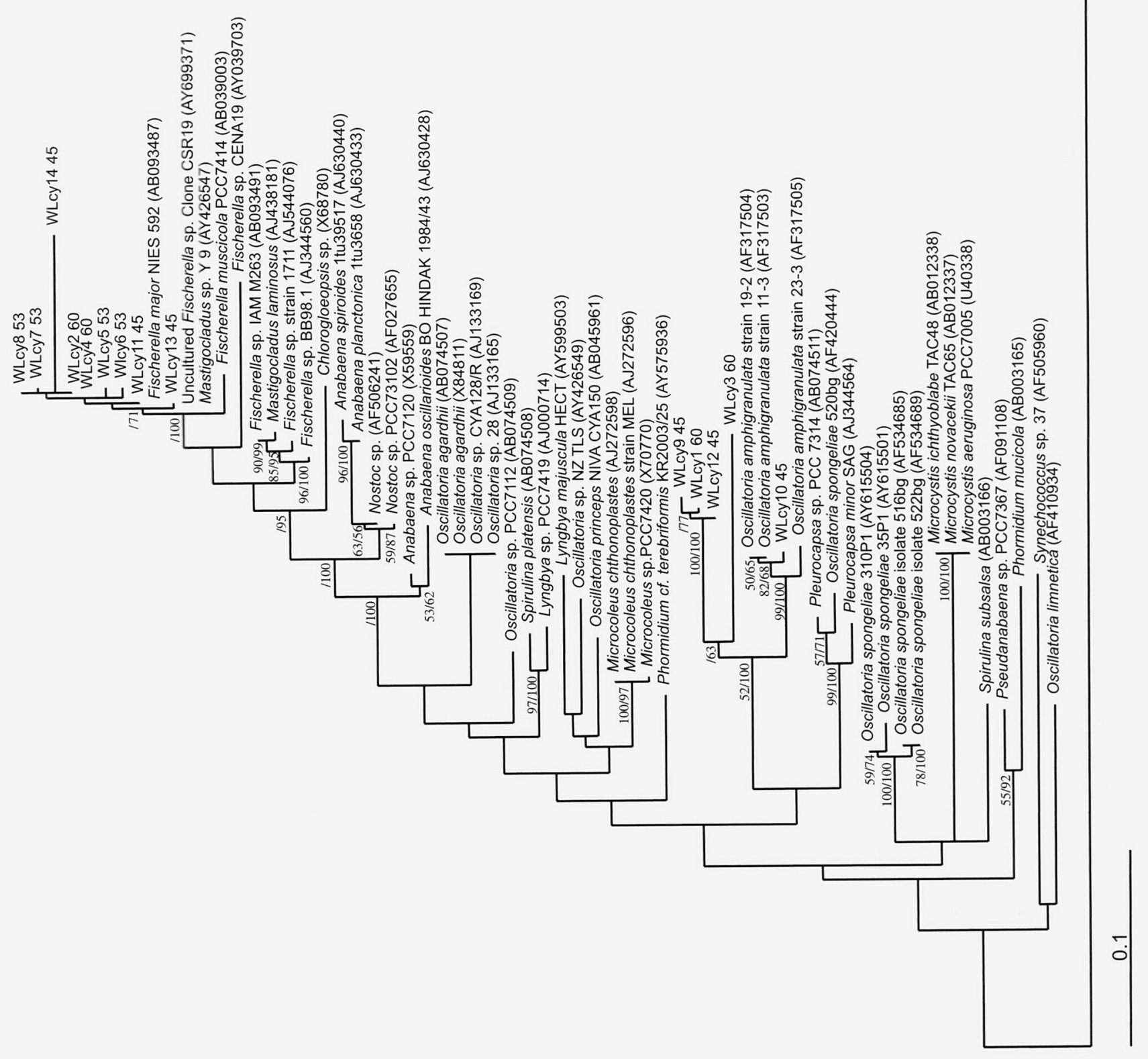


Piched and Castenholy 1991) and mycosporine-like compounds (Gatrciat-Pichel et al. 1993), although Fischerella (as Mastigocladas ef. laminosus) is not known to produce such compounds (Ward and Castenholy 2000).

The discrepancy between morphological and molecular data regarding mat composition is interesting. Oscillatoria morphotypes were not observed by microscopy. however. since the primary trichomes of Fischerella can appear similar. it is possible that if they were present in low numbers that they were not identified. It is also possible that all genotypes belong to the Fischerella morphotype. There have been other cases of $16 \mathrm{~S}$ rDNA sequences not matching observed cyanobacterial morphotypes. even in axenic culture (Nadealu et al. 2001: de la Torre et al. 2003), suggesting some phenotypic plasticity may occur among certain cyanobacterial. In the context of this study. it is believed that the Oscillatoria-like sequences probably do originate from Oscillatoria species since the genotypes are highly similar to those of known thermophilic members of this genus. Successful cultivation of Oscillatoria from these mats and seyuencing of axenic isolates would confirm this

All sequences obtained in this study were novel compared with other studies targeting this region of the $16 \mathrm{~S}$ rRNA gene. and thus expand our knowledge of genetic diversity in geothermal habitats. There was no apparent grouping of genotypes according to temperature despite apparent temperature niches among thermophilic Sinechococous genotypes being documented (Ferris et al. 1996b). Phylogenetic analyses revealed that all sequences grouped closely with those from other geothermal habitats, but distinct from mesophilic coumcrparts. Relatively few sequences have been published for Fischerella, and so our study helps to expand our phylogenetic knowledge of this genus, although the resolution provided using the partial gene sequence in this study does not allow high bootstrap support for tree topology. Targeting the complete 165 rDNA may help in resolving relationships better. The Oscillatoria-like sequences are of interest since they resolve into a distinct group with moderate support. which probably reflects a distinct phylogeographic lineage. The concept of phylogeographic lineages has been demonstrated for thermophilic Sinechococens and is attributed to isolation between geothermal habitats (Papke et al. 2003). Whether such lineages exist for Fischerella is currently unclear.

In terms of extrapolating these data to the ecology of Wonder Lake mats, the presence of abundant heterocystous cells in Fischerella-like morphotypes throughout indicates nitrogen fixation occurs in Wonder Lake mats at temperattures up to 60 "C. similar to the previously recorded maximum temperatture of 58 C for growth of this genus (Ward and Castenholy. 2000). In geothermal springs rich in combined nitrogen. Fischerella is out competed by other nonnitrogen fixing taxa (Ward and Castenholy 20(0)). suggesting Wonder Lake is a nitrogen-poor habitat. The Oscillatorialike sequences from this study shared greatest similarity to thermophilic Oscillatoria amphigramulata and Oscillatoria spp. from New Zealand that are phenotypically deficient in nitrogen assimilation (Miller and Castenhole 2(0)1). If the Oscillatoriatike sequences from Wonder Lake also possess such phenotypes. an interesting point is raised since these cells must co-exist with the diazotrophic Fischerella. Oscillatoria sequences have been recovered from geothermal springs of up to $64^{\circ} \mathrm{C}$ (Papke et al. 2003 ) and this genus is known to tolerate high sulphide levels of up to $3 \mathrm{mmol} / \mathrm{L}$ (Ward and Castenholz 20(0), so the Wonder I ake pools are a likely habitat for thermophilic members of the genus.

\section{Acknowledgements}

The authors are extremely grateful to the Philippine Institute of Volcanology and Seismology (PHIVOLCS) for advice and assistance with fieldwork. This work was supported by grants awarded to SBP and KWR by The University of Hong Kong CRCG Seed Funding for Basic Research and Small Projects programmes.

\section{References}

Arif. I.A. 1997. Composition of bluc-green algal mats and water chemistry of the Bani Malik hot spring (Gizan Province). Saudi Arabia. Kuwait J. Sci. Eng. 24: 109-121.

Brock. T.D. 1978. Thermophilic organisms and life at high temperatures. Springer Verlag. Berlin.

Castenholz. R.W. 1969. Thermophilic blue-green algate and the thermophilic environment. Bacteriol. Rev. 33: 476-504.

Castenhol\%, R.W. 1973. Ecology of hlue-green algae in hot springs. In The biology of blue-green algac. Fdited by N.G. Carr and B.A. Whitton. Blackwell. Oxford. pp. 379 414 .

Castenhol\%. R.W. 1976. The effect of sulphide on the blue-green algate of hot springs. I. New Zealand and lecland. J. Phycol. 12: $54-68$.

Castenhol\%. R.W. 1996. Endemism and biodiversity of thermophilic cyanobacteria. Nova Hedwigia, 112: 3.3-47.

Castenhol\%, R.W., and Garcia-Pichel, F. 2000). Cyanobacterial responses to UV-radiation. In The Feology of cyanobacteria. Edited by B.A. Whiton and M. Potts. Kluwer Academic Publishers, Dordrecht. pp. 591-611.

Collier, J.L.. and Grossman. A.R. J992. Chlorosis induced by nutrient deprivation in Sinechocecens sp. Strain PCC7942: not all bleaching is the same. J. Bacteriol. 174: $4718-4726$.

de la Torre, J.R., Goebel, B.M., Friedmann, E.l., and Pace, N.R. 2003. Microbial diversity of eryptoendolithic communities from the Mc.Murdo dry valleys, Antarctica. Appl. Environ. Microbiol. 69: $3858-3867$.

Doyle, J.J., and Doyle. J.I. 1987. A rapid DNA isolation procedure for small quantities of fresh kat tissue. Phytochem. Bull. 19: $11-15$.

Ferris, M.J., and Ward. D.M. 1997. Seasonal distributions of dominant $16 \mathrm{~S}$ rRNA-defined populations in a hot spring microbial mat examined by denaturing gradient gel electrophoresis. Appl. Environ. Microbiol. 63: 137.5-1381.

Ferris, M.J. Ruff-Roberts, A.L.. Kopeynshi, E.D., Bateson, M.M., and Ward, D.M. 1996a. Enrichment culture and microscopy conceal diverse themophilic Sinechorocews populations in a single hot spring microbial mat habitat. Appl. Environ. Microbiol. 62: $1045-1050$.

Ferris, M.J., Muyzer, (j., and Ward. I).M. 1996h. Denaturing gradient gel clectrophoresis profiles of $16 \mathrm{~S}$ rRNA-defined populalions inhabiting a hot spring microbial mat community. Appl. Environ. Microbiol. 62: 340-346.

Ferris. M.J., Nold. S.C., Revshech, N.P., and Ward, D.M. 1997. Population structure and physiological changes within a hot spring microbial mat community following disturbance. Appl. Environ. Microbiol. 63: 1.367-1.374. 
Garcia-Pichel, F., and Castenholz, R.W. 1991. Characterization and biological implications of scytonemin, a cyanobacterial sheath pigment. J. Phycol. 27: 395-409.

Garcia-Pichel, F., Wingard. C.E., and Castenholz, R.W. 1993. Evidence regarding the $\mathrm{UV}$-sunscreen role of a mycosporine-like compound in the cyanobacterium Gloeocapsa sp. Appl. Environ. Microbiol. 59: 170-176.

Hall, T.A. 1999. BioEdit: a user-friendly biological sequence alignment editor and analysis program for Windows 95/98/NT. Nucleic Acids Symp. Ser. 41: 95-98.

Miller, S.R., and Castenholz, R.W. 2001. Ecological physiology os Synechococcus sp. Strain SH-94-5, a naturally occurring cyanobacterium deficient in nitrate assimilation. Appl. Environ. Microbiol. 67: 3002-3009.

Myers, R.M., Sheffield, V.C., and Cox, D.R. 1988. Detection of single base changes in DNA: ribonuclease cleavage and denaturing gradient gel electrophoresis. In Genome analysis, a practical approach. Edited by K.E. Davies. IRL Press, Oxford. pp. 95-139.

Nadeau, T.L., Milbrandt, E.C., and Castenholz, R.W. 2001. Evolutionary relationships of cultivated Antarctic oscillatorians (cyanobacteria). J. Phycol. 37: 650-654.

Norris, T.B., McDermott, T.R., and Castenholz, R.W. 2002. The long-term effects of UV exclusion on the microbial composition and photosynthetic competence of bacteria in hot-spring microbial mats. FEMS Microbiol. Ecol. 39: 193-209.

Nübel, U., Garcia-Pichel. F., and Muyzer, G. 1997. PCR primers to amplify 16S rRNA genes from cyanobacteria. Appl. Environ. Microbiol. 63: 3327-3332.

Panyoo, W., and Peerapornpisal, Y. 2001. Screening of thermotolerant blue-green algae from some hot springs in Thailand. Phycologia, 40(S): 101.

Papke, R.T., Ramsing, N.B., Bateson, M.M., and Ward, D.M. 2003. Geographical isolation in hot spring cyanobacteria. Environ. Microbiol. 5: 650-659.

Pentecost, A. 1995. The microbial ecology of some Italian hotspring travertines. Microbios, 81: 45-58.
Pentecost, A., Bayari, S., and Yesertener, C. 1997. Phototrophic microorganisms of the Pamukkale Travertine, Turkey: their distribution and influence on travertine depostion. J. Geomicrobiol. 14: $269-283$.

Rannala, B., and Yang, Z.H. 1996. Probability distribution of molecular evolutionary trees: a new method of phylogenetic inference. J. Mol. Ecol. 43: 304-311.

Swofford, D.L. 2001. PAUP*: Phylogenetic Analysis Using Parsimony (*and other methods) Version 4.0b8. Sinauer Associates, Sunderland, Mass.

Ward, D.M., and Castenholz, R.W. 2000. Cyanobacteria in geothermal habitats. In The ecology of cyanobacteria. Edited by B.A. Whitton and M. Potts. Kluwer Academic Publishers, Dordrecht. pp. 37-59.

Ward, D.M., Tayne, T.A., Anderson, K.L., and Bateson, M.M. 1987. Community structure, and interactions among community members in hot spring cyanobacterial mats. Symp. Soc. Gen. Microbiol. 41: 179-210.

Ward, D.M., Weller, R., Shiea, J., Castenholz, R.W., and Cohen, Y. 1989. Hot spring microbial mats: anoxygenic and oxygenic mats of possible evolutionary significance. In Microbial mats: physiological ecology of benthic microbial communities. Edited by Y. Cohen and E. Rosenburg. Am. Soc. Microbiol., Washington, DC. pp. 3-15.

Ward, D.M., Santagoeds, C.M., Nold, S.C., Ramsing, N.B., Ferris, M.J., and Bateson, M.M. 1997. Biodiversity within hot spring microbial mat communities: molecular monitoring of enrichment cultures. Antonie van Leeuwenhoek, 71: 143-150.

Ward, D.M., Ferris, M.J., Nold, S.C., and Bateson, M.M. 1998. A natural view of microbial biodiversity within hot spring cyanobacterial mat communities. Microbiol. Mol. Biol. Rev. 62: 13531370. 